\title{
Note on Names
}

Following are the names of the coauthors and their immediate family. Yelena and Galina Lembersky's names are followed by the nicknames or the diminutives by which they were known in Russia. All other people in the accountfriends, neighbors, coworkers, or prison inmates-are real, but some names have been changed.

Alëna (pronounced Ale-yóna), aka Alënushka, Alënka, Alëshenka, Yelena Lembersky: daughter of Galia and narrator of Parts One and Three

Galia, Galka, Galina Lembersky: mother of Alëna, daughter of Felix and Lucia Lembersky, and narrator of Part Two

Felix Lembersky (1913-1970): grandfather of Alëna, father of Galia, husband of Lucia. A prominent artist born in Lublin, Poland, raised in Berdichev, Ukraine, educated at Kultur-Lige and the Art Institute in Kiev, and the Academy of Art in Leningrad

Lucia, Lucy, Lucinka Lembersky (1915-1994): wife of Felix Lembersky, mother of Galia, and grandmother of Alëna

Mikhail Ksendzovsky: uncle of Lucia Lembersky. Singer, actor, and director of the Theater of Musical Comedy and the Summer Theater at Sad Otdikha in Petrograd-Leningrad in the 1910 s and '20s 



\section{PART ONE}

\section{Alëna}

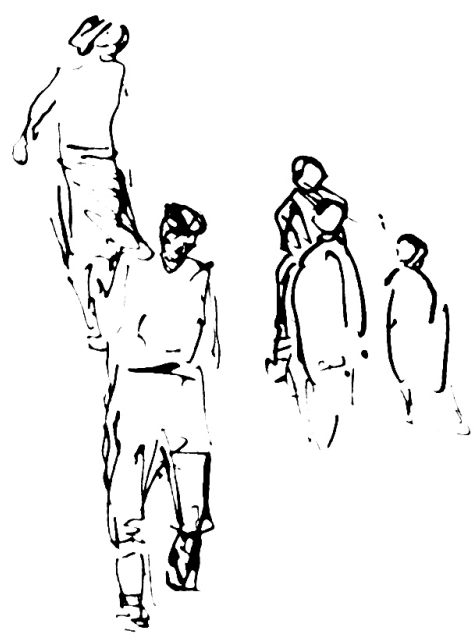


